\title{
GEOMETRICAL CHARACTERISTIC OF SCOUR HOLES CAUSED BY OVERTOPPING FLOW OF EMBANKMENT COVERED WITH DIFFERENT LENGTHS OF PROTECTION WORKS
}

\author{
Doan Van BINH ${ }^{1}$, Sazia AFREEN ${ }^{2}$, Junji YAGISAWA ${ }^{3}$ and Norio TANAKA ${ }^{4}$ \\ ${ }^{1}$ Member of JSCE, Master Student, Graduate School of Science and Engineering, Saitama University \\ (225 Shimo-Okubo, Sakura-Ku, Saitama 338-8570, Japan) \\ ${ }^{2}$ Member of JSCE, Doctoral Student, Graduate School of Science and Engineering, Saitama University \\ (225 Shimo-Okubo, Sakura-Ku, Saitama 338-8570, Japan) \\ ${ }^{3}$ Member of JSCE, Ph.D., Assistant Professor, Graduate School of Science and Engineering, Saitama University \\ (225 Shimo-Okubo, Sakura-Ku, Saitama 338-8570, Japan) \\ ${ }^{4}$ Member of JSCE, Dr. Eng., Professor, International Institute for Resilient Society, Saitama University \\ (225 Shimo-Okubo, Sakura-Ku, Saitama 338-8570, Japan)
}

\begin{abstract}
Scouring downstream of hydraulic structures is a complex phenomenon that causes the instability and even the failure of the structures. This experiment-based research was conducted to study the effect of the protection work length, $L$, along the embankment landside slope on the relationship between non-dimensional scour depth $\left(S_{D} / L \sin \theta\right)$ and its location $\left(S_{P} / L \cos \theta\right)$ under various overtopping flow depths $\left(S_{D}\right.$ : maximum scour depth, $S_{P}$ : the location of $S_{D}$, and $\theta$. the landside slope angle). For evaluating the possibility of the fragility of the embankment landside slope, a schematic diagram based on the angle of repose of foundation behind embankment toe is proposed in this study. The result shows that the effect of the protection work length on the risk of the embankment landside slope fragility are classified into 3 types according to the variation of the overtopping flow depths.
\end{abstract}

Key Words : Scour, sea embankment, protection works, overtopping flow, fragility of the embankment landside slope

\section{INTRODUCTION}

The Great East Japan tsunami in 2011 caused tremendous damage to human lives and socio-economic properties in Tohoku region of Japan. Some sea embankments were found to be failed by large overtopping flow which caused the breaching of the embankments. In addition, scour at the landside near the embankment toe was one of the main reasons of the fragility of embankment slope. Therefore investigation of the scour characteristics under overtopping flow is necessary.

Scouring downstream of hydraulic structures is a complex phenomenon that causes the instability and even the failure of the structures. Understanding the formation mechanism of local scour has been concerned by many researchers. Scour downstream of sluice gate, in particular, was extensively studied by Kells et al. ${ }^{1)}$, and Dey and Sarkar ${ }^{2)}$. Kells et al. ${ }^{1)}$ investigated the effect of grain size on local scour below a sluice gate. They concluded that reducing the grain size leads to the increase of both scour depth and scour area. In the research of Dey and Sarkar ${ }^{2)}$, they found that the equilibrium scour depth decreases with increasing the sediment size and sluice opening.

Besides, scour induced by overtopping flow downstream of grade-control structures (similar with weirs and cross-vane structures) was also studied by some researchers. Bormann and Julien ${ }^{3)}$ investigated the local scour downstream of grade-control structure. The results showed that equilibrium scour depth is a function of velocity, flow depth and particle size. D'Agostino and Ferro ${ }^{4)}$ conducted a research of scour on alluvial bed downstream of grade-control structures. The results pointed out that the scour depth in both small and large scale installations can be explained by the ratio between the upstream water head and the weir height. 
Dealing with the scouring problem, scour countermeasures were studied by some researchers and even widely applied in over the world. Pagliara and Palermo ${ }^{5}$ studied the effects of rock sill in the stilling basin downstream of block ramp on scour property. They concluded that scour characteristics were strongly dependent on the location of the rock sill in the stilling basin because the sill made a change of hydrodynamic conditions. Johnson et al. ${ }^{6}$ ) compared the effectiveness among four types of scour protection: riprap, coreloc, riprap with underlayer, and coreloc with underlayer. It is found that riprap with underlayer showed a significant improvement of minimizing the scour hole size.

Obviously, these usual scour countermeasures (riprap, coreloc, etc.) remain a limitation in terms of land use behind embankments. On the one hand, it requires large space in constructing scour countermeasures themselves. One the other hand, scour hole is still occurred behind these protection works that makes the extent of the scour hole from the embankment landside toe wide. Therefore, in this research, the protection work along the embankment landside slope has been conducted, which not only protects the embankment landside slope from fragility but also is expected to reduce the extent of the scour hole. This kind of the protection work may be applicable for coastal areas where the distance between sea embankment and urban infrastructures is short, the usual methods (riprap, coreloc, etc.) are not suitable.

In short, scour at the landside of sea embankments due to the overtopping flow induced by tsunamis even though causes severe damage, very limited studies concerns this issue. Therefore, this study pays attention to that phenomenon. The objectives of this study are (1) to investigate the relationship between the maximum scour depth and scour length at the equilibrium condition, and (2) to study the effect of the length of the protection work along the embankment landside slope on the relationship between the maximum scour depth and its distance from the toe of the embankment under various overtopping flow depths.

\section{EXPERIMENT SETUP}

The experiment was conducted in a re-circulating flume which is $4 \mathrm{~m}$ long, $0.4 \mathrm{~m}$ wide and $0.5 \mathrm{~m}$ high in Hydraulic Engineering Laboratory of Saitama University, Japan. The embankment model was set up, in which impermeable surfaces were covered by wooden plates as shown in Fig. 1. The landside slope of the embankment, $S$, was 1:3 (corresponding to the angle of $\theta=18.42$ degree). A soil layer with median diameter, $d_{50}$, of $4.47 \mathrm{~mm}$ was placed at the

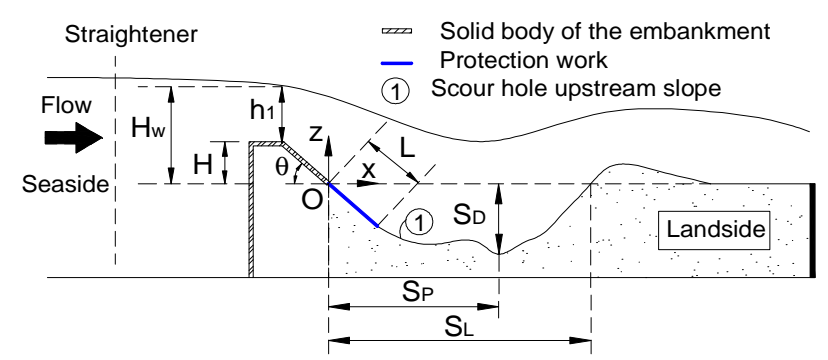

Fig. 1 Schematic of the experiment setup

Table 1 Experimental condition

\begin{tabular}{|c|c|c|c|c|c|c|c|}
\hline $\begin{array}{c}\text { Experiment } \\
\text { RUN }\end{array}$ & $h_{l} / H$ & $L / H$ & $\begin{array}{c}\mathrm{T} \\
(\mathrm{min})\end{array}$ & $\begin{array}{c}\text { Experiment } \\
\mathrm{RUN}\end{array}$ & $h_{I} / H$ & $L / H$ & $\begin{array}{c}\mathrm{T} \\
(\mathrm{min})\end{array}$ \\
\hline \hline 1 & 0.1 & 0 & 300 & 9 & 0.1 & 1.0 & 30 \\
\hline 2 & 0.2 & 0 & 300 & 10 & 0.2 & 1.0 & 30 \\
\hline 3 & 0.3 & 0 & 300 & 11 & 0.3 & 1.0 & 30 \\
\hline 4 & 0.4 & 0 & 30 & 12 & 0.4 & 1.0 & 30 \\
\hline 5 & 0.1 & 0.5 & 30 & 13 & 0.1 & 1.5 & 30 \\
\hline 6 & 0.2 & 0.5 & 30 & 14 & 0.2 & 1.5 & 30 \\
\hline 7 & 0.3 & 0.5 & 30 & 15 & 0.3 & 1.5 & 30 \\
\hline 8 & 0.4 & 0.5 & 30 & 16 & 0.4 & 1.5 & 30 \\
\hline
\end{tabular}

landside from the embankment toe (point $\mathrm{O}$ in Fig. 1). The length of the soil layer is $2 \mathrm{~m}$ from the toe of the embankment landside slope. At the end of soil layer, a wooden plate (solid part in Fig. 1) was used to retain soil particles against sliding under pressure of the water flow. The soil surface was leveled at 10 $\mathrm{cm}$ lower than the top of the embankment (defined as $H$ in Fig. 1). For all cases of the experiment, $H$ was considered at that unchanged value. At the end of the flume, water goes freely into the water tank.

Water flow was controlled by a recirculation pump located downstream of the experiment section. In front of the embankment, there was a straightener which allowed water overtopping the embankment steadily by absorbing unexpected waves and turbulences. The $h_{1} / H$ ratios $\left(h_{1}=\right.$ overtopping flow depth) were $0.1,0.2,0.3$, and 0.4 by adjusting a valve in the pump pipe. Before starting each experiment, soil was leveled at a desirable thickness. Water was then pumped in slowly till reaching an expected overtopping flow depth. Thereafter, the flow rate was controlled to maintain that water depth.

The main parameters of the scour hole analyzed in this paper were maximum scour depth, $S_{D}$, scour length, $S_{L}$, and the maximum scour location, $S_{P}$ (Fig.1). A protection work was placed continuously with the landside slope of the embankment to protect the foundation of the embankment from undermining induced by scour hole. Four cases of the length of the protection work, $L$, were used in this study: one based case $(L / H=0$ - no protection work) and other three cases are $L / H=0.5,1$, and 1.5 , respectively.

By changing the overtopping flow depth and the 
length of the protection work, 16 cases were totally carried out in this study (Table 1). After each case, two dimensional bed profile along the experiment channel (horizontal and vertical dimensions) was measured by a point gauge with the accuracy of $\pm 0.1 \mathrm{~mm}$. During the measurement, videos were recorded for analyzing the flow pattern and the development of the scour hole. The origin of the coordinates $(x, z)$ was always at the toe of the landside slope in case of without protection work as shown in Fig.1. In the present research, the scour parameters (maximum scour depth, length and the location of maximum scour depth) were discussed at its equilibrium condition.

\section{RESULTS AND DISCUSSIONS}

\section{(1) Relationship between maximum scour depth} and scour length at equilibrium condition

All experiment runs were done in "clear water condition"7),8). To determine a necessary time for obtaining the equilibrium condition, in runs: 1,2 , and 3 (see Table 1), the experiment was continued till the scour hole profile became unchanged. Maximum scour depth and length were then analyzed with the time variation as illustrated in Fig. $2 \mathrm{a}$ and $\mathrm{b}$. In these two figures, $t$ is the time variable; $T$ is the total experiment time $(T=300 \mathrm{~min}) ; S_{D, t}$ and $S_{L, t}$ are maximum scour depth and length at $t$ respectively; $S_{D}{ }^{*}$ and $S_{L} *$ are maximum scour depth and length at $T$ respectively. It can be seen that the scour develops rapidly after starting the experiment, then gradually increases till getting its equilibrium condition. In addition, both maximum scour depth and length become equilibrium from $t / T=0.1$ ( $t=$ 30 minutes). Therefore, "30 minutes" is considered as the time of reaching the equilibrium condition. This time is in accordance with the time discussed in Pagliara et al. ${ }^{8)}$ where the scour configuration at the equilibrium state in clear water condition is pointed out to be generally achieved after 30 minutes when coarse sediment $\left(d_{50}>3 \mathrm{~mm}\right)$ was used. Since then, this study discusses maximum scour depth, length and the location of the maximum scour depth at the equilibrium state, referring as $S_{D}, S_{L}$, and $S_{P}$, respectively.

Fig. $2 \mathrm{a}$ and $\mathrm{b}$ show that in the process of reaching the equilibrium state, scour length develops faster than scour depth (the development rate of maximum scour length and depth are $14 \%$ and $8 \%$ respectively). The development rate is defined as

$$
\text { Development rate }=\frac{A_{t / T=0.1}-A_{t / T=0.02}}{A_{t / T=0.02}} \times 100(\%)
$$

where $A_{t / T=0.1}$ is maximum scour depth or scour length at $t / T=0.1$, and $A_{t / T=0.02}$ is maximum scour
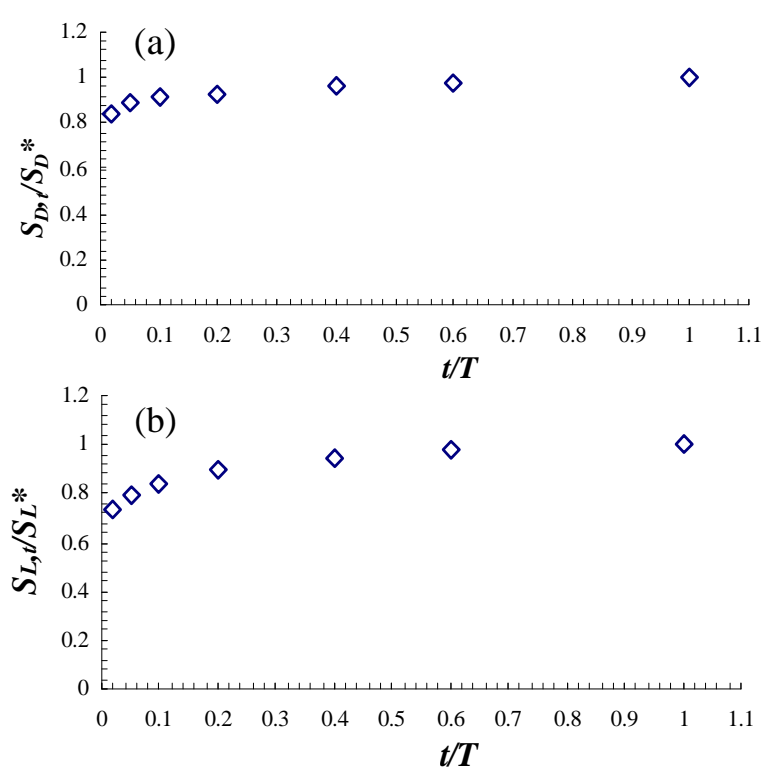

Fig. 2 Time variation of (a) maximum scour depth and (b) maximum scour length in case $L / H=0$ and $h_{l} / H=0.3$ (RUN 3)

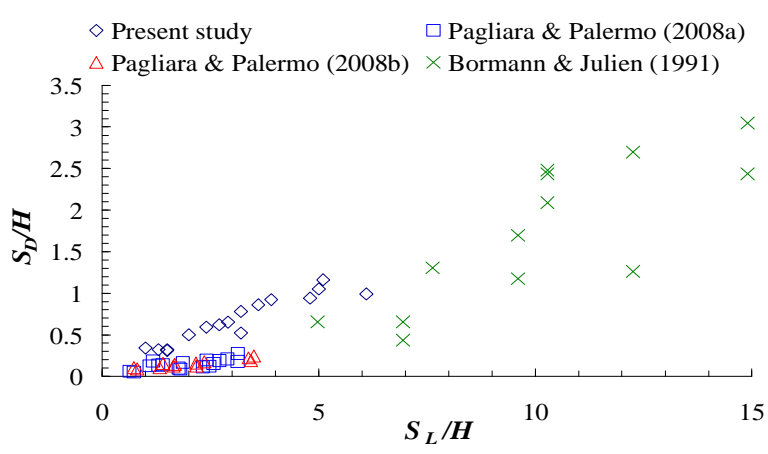

Fig. 3 Relationship between maximum scour depth and length at the equilibrium state

Table 2 Comparison of the experimental conditions

\begin{tabular}{|c|c|c|c|}
\hline Paper & $\begin{array}{c}\text { Present } \\
\text { study }\end{array}$ & $\begin{array}{c}\text { Bormann } \\
\text { \& Julien }\end{array}$ & $\begin{array}{c}\text { Pagliara \& } \\
\text { Palermo 5),9 }^{5}\end{array}$ \\
\hline \hline Landside slope $S$ & 0.32 & $0.32-0.79$ & $0.08-0.25$ \\
\hline Structure width $b(\mathrm{~m})$ & 0.40 & 0.91 & 0.25 \\
\hline Channel width $B(\mathrm{~m})$ & 0.40 & 0.91 & 0.25 \\
\hline Unit discharge $q\left(\mathrm{~m}^{2} / \mathrm{s}\right)$ & $0.01-0.11$ & $0.32-1.47$ & $0.01-0.04$ \\
\hline Structure height $H(\mathrm{~m})$ & 0.10 & 0.23 & $0.08-0.25$ \\
\hline Overtopping flow depth $h_{l}(\mathrm{~m})$ & $0.01-0.05$ & $0.12-1.10$ & $0.02-0.05$ \\
\hline Median soil diameter $d_{50}(\mathrm{~mm})$ & 4.50 & 0.45 & $5.10-6.10$ \\
\hline
\end{tabular}

depth or scour length at $t / T=0.02$. This is because the stagnant water in the scour hole obstructs the water jet directly impinging into the mobile bed in vertical direction. However, the longitudinal component of the flow still carries the soil particles downstream in the horizontal direction. Therefore, the size of scour length is relatively larger than scour depth size at the equilibrium state.

Fig. 3 shows the relationship between the maximum equilibrium scour depth and length. The results of previous studies ${ }^{3), 5), 9)}$ are also plotted in this Figure. Bormann and Julien ${ }^{3)}$ investigated the 
local scour downstream of grade-control structures using a large-scale flume experiment. In the other two studies ${ }^{5,9)}$, experiments have been conducted in small-scale flumes to analyze the local scour downstream of block ramps. In these three studies, experiments without protection work out of their experiment data sets were chosen for the comparison. In general, scour depth increases linearly with increasing scour length (Fig.3) even experimental conditions of each study are different as shown in Table 2. The relationship between scour depth and length obtained in present study also shows similar tendency with previous researches. In addition, this tendency does not change in any length of the protection work.

\section{(2) Influence of flow patterns on the scour formation}

Figure $4 \mathrm{a}$ and $\mathrm{b}$ show the flow patterns around scour hole under different overtopping flow depths $\left(h_{1} / H=0.2\right.$ and 0.4 respectively) and same protection work length $(L / H=0)$. In case of without protection work (Fig. 4a), the flow direction is dominant by the horizontal component for small overtopping flow depths $\left(0.1 \leq h_{1} / H \leq 0.3\right)$. For larger overtopping flow depth $\left(h_{1} / H=0.4\right)$, the flow is very strong near the water surface due to the formation of a free hydraulic jump (Fig. 4b). Fig. 5 shows that relative energy dissipation, $\left(E_{1}-E_{2}\right) / E_{1}$, (where $E_{l}$ is energy head at the downstream edge of the embankment crest, and $E_{2}$ is energy head at the section after the jump) of free hydraulic jump is smaller than that of submerged hydraulic jump ${ }^{10)}$. Thus, huge energy induced by such free hydraulic jump causes the transport of huge amount of soil particles from the movable bed near the embankment toe at the landside to downstream section. As a result, large scour hole is observed. More importantly, there is a secondary ridge presenting in the scour hole (Fig. $4 \mathrm{~b}$ ) beside the main ridge which is downstream of the scour hole. It is because the flow which is dropping after the jump (referred as dropping flow) carries the soil particles upstream. After a certain time, those soil particles are accumulated in the scour hole and formed the secondary ridge.

On the contrary, with the appearance of the protection work (Fig.4c), the main flow direction is parallel to the embankment landside slope due to the orientation of the protection work for all values of the overtopping flow depths. The main flow is overlaid by a mass of water above induced by submerged hydraulic jump. Therefore, the vertical flow component is larger than the horizontal flow component, which impinges directly to the mobile bed. Moreover, the recirculation flow component of the submerged hydraulic jump in the scour hole
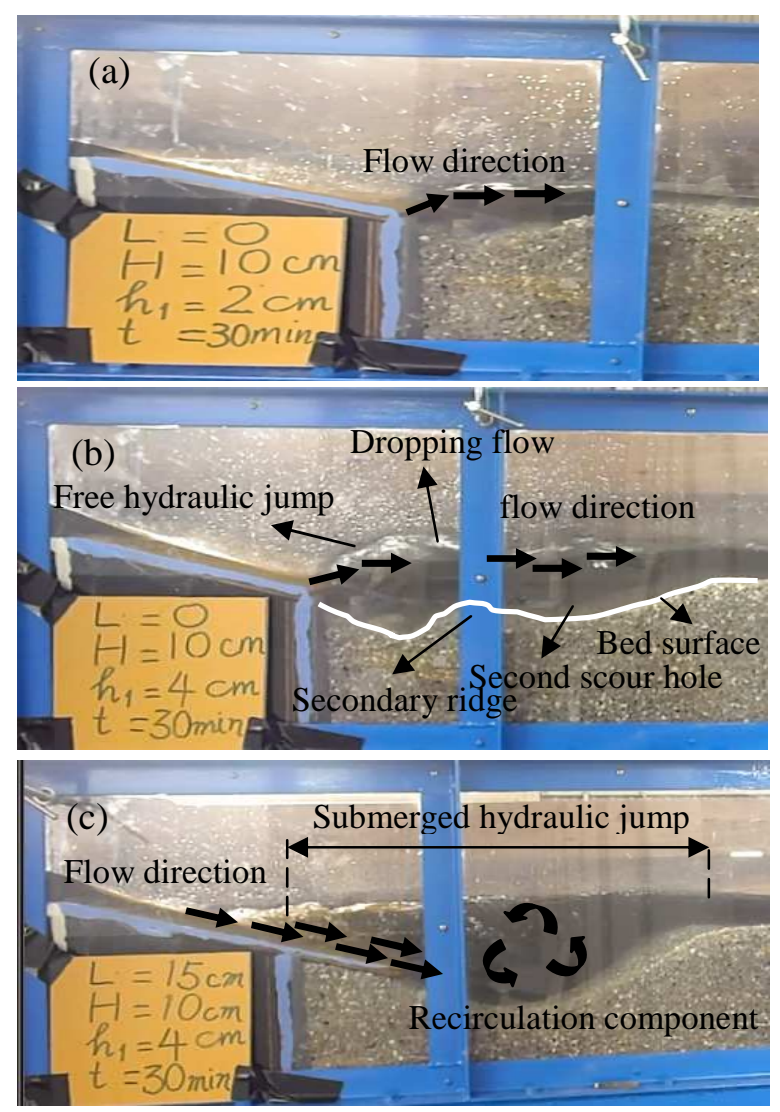

Fig. 4 Representatives of the flow patterns (a) without protection work - no hydraulic jump, (b) without protection work - free hydraulic jump, (c) with protection work submerged hydraulic jump

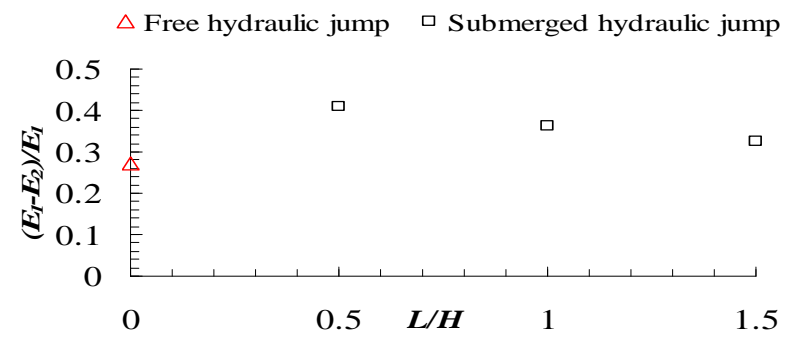

Fig. 5 Relationship between the protection work length and relative energy dissipation within hydraulic jump for $h_{l} / H=0.4$

increases removing soil particles from the bed. Those soil particles are then blown downstream due to the horizontal component of the flow. As a consequence, a large scour hole is observed in the presence of the protection work compared to that without it.

\section{(3) The effect of the length of protection work on the maximum scour depth and its location}

When the scour depth exceeds the height of the protection work and its location is close to the embankment toe, the risk of the fragility of the embankment landside slope supposes to be high. It is therefore important to clarify the effect of the protection work length on maximum scour depth $\left(S_{D}\right)$ and its location $\left(S_{P}\right)$ under various overtopping 
flow depths. To investigate that effect of protection work length on the risk of embankment landside slope fragility, it seems that the maximum scour length, $S_{L}$, is likely not well-performed in comparison with $S_{D}$ and $S_{P}$. Therefore, $S_{P}$ and $S_{D}$ are discussed mainly in this section.

Non-dimensional maximum scour depth, $S_{D} / H$, and non-dimensional location occurred maximum scour depth, $S_{P} / H$ in relation with the length of the protection work are shown in Fig. $6 a$ and $6 b$, respectively. It can be seen from Fig. 6a that for $h_{1} / H=0.1$, the values of $S_{D} / H$ does not much change. It is simply because the flow energy induced by this overtopping flow depth is not strong enough to carry soil particles downstream in spite of with or without the protection work. When $h_{1} / H$ is in between 0.2 and 0.3 , increasing the protection work length leads to the increment of the $S_{D} / H$. However, when the value of $h_{1} / H$ is 0.4 , the $S_{D} / H$ becomes minimum at $L / H=0.5$. It can be explained from Fig. 5 that at this value of $L / H$, the flow energy is much dissipated due to the occurrence of the submerged hydraulic jump (the representative of the extent of submerged hydraulic jump can be seen in Fig. 4c); on the other hand, the protection work length is not long enough to increase digging the movable bed.

Fig. $6 \mathrm{~b}$ shows the relationship between $S_{P} / H$ and $L / H$. When $h_{1} / H$ ranges from 0.1 to 0.3 , the maximum scour location increases with increasing the length of the protection work. However when $h_{1} / H=0.4$, the maximum scour location, $S_{P} / H$, are closest to the embankment toe at $L / H=0.5$. Since at this value of $L / H$, the flow energy is much dissipated due to the appearance of the submerged hydraulic jump (Fig. 5). Therefore soil particles far from the embankment toe become difficult to be flushed away.

Obviously, the risk of the embankment landside slope fragility is dependent on both $S_{D}$ and $S_{P}$. The relationship between non-dimensional scour depth $\left(S_{D} / L \sin \theta\right)$ and its location $\left(S_{P} / L \cos \theta\right)$ therefore is used to categorize the degree of the influence of the protection work length on the risk of structure slope fragility (Fig. 7). In this figure, the angle of repose which represents the threshold of the embankment landside slope undermining is included by a red line. Referring the research of Dey and Sarkar ${ }^{2}$, the angle of repose in this research is $\theta^{*}=35.5$ degree.

In Fig. 7, it can be categorized into 5 regions to represent the embankment landside slope to be "safe" or "dangerous" of being fragile:

Region A: $S_{D} / L \sin \theta$ and $S_{P} / L \cos \theta$ are both smaller than 1. That means maximum scour depth and its location occurred do not exceed the extent of the protection work, therefore, the embankment
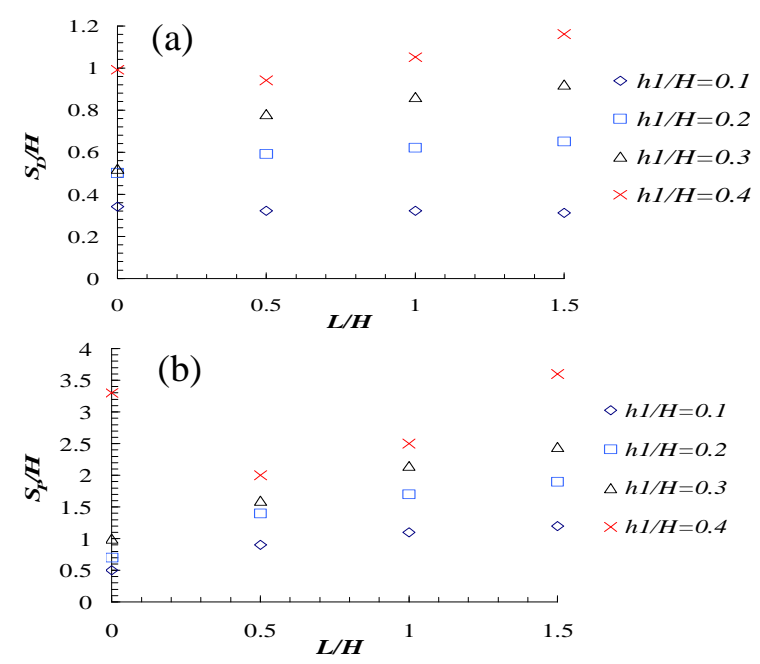

Fig. 6 Relationship between the length of the protection work and (a) maximum scour depth, (b) maximum scour location

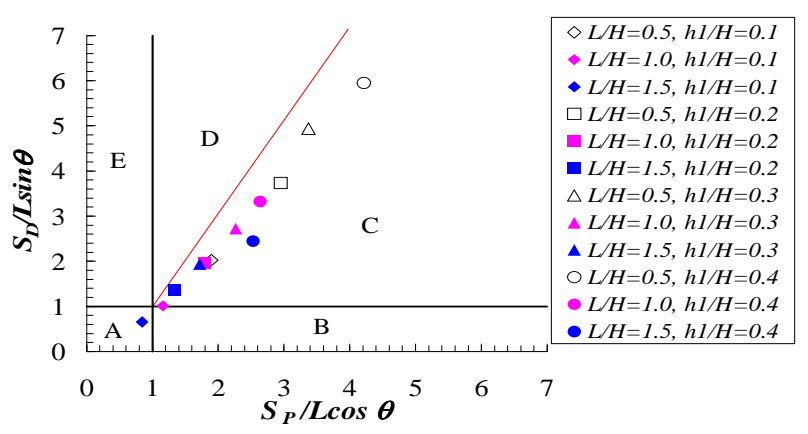

Fig. 7 Relationship between non-dimensional scour depth and its location

landside slope becomes "safe" to be fragile.

Region B: maximum scour depth is above the protection work $\left(S_{D} / L \sin \theta<1\right)$ while scour location is $\operatorname{far}\left(S_{P} / L \cos \theta>1\right)$. Therefore, this region is supposed to be "safe" from fragility.

Region C: $S_{D} / L \sin \theta$ and $S_{P} / L \cos \theta$ are both greater than 1 and below the threshold of the failure of the scour hole upstream slope. Therefore, the embankment landside slope is "safe" from undermining.

Region D: $S_{D} / L \sin \theta$ and $S_{P} / L \cos \theta$ are both greater than 1 and above the threshold of the failure of the scour hole upstream slope. It is therefore obvious that this region is appearing to be "dangerous" of the fragility of the embankment landside slope.

Region E: scour location is within the extent of the protection work $\left(S_{P} / L \cos \theta<1\right)$ but the scour depth exceeds the protection work in vertical direction $\left(S_{D} / L \sin \theta>1\right)$. If this region may appear, the embankment landside slope is supposed to be "dangerous". Nonetheless, this kind of scouring is never occurred in the reality.

In this research, all cases of the experiment without protection work $(L / H=0)$ are in region $\mathrm{D}$, one case happened in region $\mathrm{A}\left(L / H=1.5, h_{1} / H=\right.$ 0.1 ), and the rest are falling into region $\mathrm{C}$. 
Therefore, in this research, the embankment landside slope is at risk of fragility in case of without any protection, but is difficult to be fragile by using the protection work. Moreover, the insight assessment of the effect of protection work length on the risk of the fragility of the embankment landside slope should be carried out.

Study the tendency effect of the protection work length on the embankment landside slope, it can be classified into 3 types according to the change of the overtopping flow depth $h_{1} / H$ (Fig. 7):

Type 1: $h_{1} / H=0.1$. When the protection work length is long, the landside foundation of the embankment is better protected and therefore is "safe" from fragility. It can be explained that the flow energy is small with small overtopping flow depth, when increasing the length of the protection work, the scour hole occurs just above the protection work and does not cause any risk to the embankment landside slope.

Type $2: h_{1} / H=0.2$ and 0.3 . The scour tends to cause higher risk to the embankment landside slope when increasing the protection work length. It is because when increasing the protection work length, the scour hole upstream slope approaches the threshold of its failure.

Type 3: $h_{1} / H=0.4$. Increasing the protection work length up to some values $(0.5<L / H<1.0)$, the embankment landside slope becomes at risk to be fragile because the red circle dot is approaching to the threshold line (Red line in Fig.7). However when increasing the protection work length $(L / H>$ 1.0), the blue circle dot is apart from the threshold line. This result indicates that in the case of $h_{1} / H=$ 0.4 , intermediate protection work length $(L / H=1.0)$ should not be used for reducing the possibility of embankment landside slope fragility.

\section{CONCLUSION}

This experimental study is investigated scour characteristics as like $S_{D}, S_{L}$ and $S_{P}$ at the equilibrium condition under various overtopping flow depths. In addition, for elucidating the effect of the protection work length on the risk of the embankment slope fragility, $S_{D} / L \sin \theta$ and $S_{P} / L \cos \theta$ are used. The results are summarized as following:

1. Regardless of having the protection work, scour depth linearly increases with the increase of the scour length. That trend is similar with three previous researches without the protection work $^{3,5), 9)}$.

2. In the relationship between $S_{D} / L \sin \theta$ and $S_{P} / L \cos \theta$, the effect of the protection work length on the risk of the embankment landside slope fragility are categorized into 5 regions, varying from "safe" to "dangerous". While cases without protection work tend to threaten the embankment landside slope from fragility, cases with protection work have otherwise effect.

The tendency effect of the protection work length on the embankment landside slope fragility are classified into 3 types: 1) increasing the protection work length helps the embankment landside slope become better protected (Type 1), 2) Increasing the protection work length tends to cause higher risk to the embankment landside slope fragility (Type 2), and 3 ) the possibility of embankment landside slope fragility is highest by using intermediate protection work length (Type 3).

\section{ACKNOWLEDGEMNET}

This study was partly funded by a JSPS Grant-in-Aid for Scientific Research (B) (No. 24310127) and JSPS Grant-in-Aid for Young Scientists (B) (26821097). Authors would like to thank to Mr. Miyashita for his help in experiments.

\section{REFERENCES}

1) Kells, J. A., Balachandar, R. and Hagel, K. P.: Effect of grain size on local channel scour below a sluice gate, Canadian Journal of Civil Engineering, Vol. 28, No. 3, pp. 440-451, 2001.

2) Dey, S. and Sarkar, A.: Scour downstream of an apron due to submerged horizontal jets, Journal of Hydraulic Engineering, Vol. 132, No. 3, pp. 246-257, 2006.

3) Bormann, N. E. and Julien, P. Y.: Scour downstream of grade -control structures, Journal of Hydraulic Engineering, Vol. 117, No. 5, pp.579-594, 1991.

4) D'Agostino, V. and Ferro, V.: Scour on alluvial bed downstream of grade-control structures, Journal of Hydraulic Engineering, Vol. 130, No. 1, pp. 24-37, doi: 10.1061/(ASCE)0733-9429(2004) 130:1(24), 2004.

5) Pagliara, S. and Palermo, M.: Scour control and surface sediment distribution downstream of block ramps, Journal of Hydraulic Research, Vol. 46, No. 3, pp. 334-343, 2008.

6) Johnson, E. B., Testik, F. Y., Ravichandran, N. and Schooler, J.: Levee scour from overtopping storm waves and scour counter measures, Ocean Engineering, Vol. 57, pp.72-82, 2013.

7) Pagliara, S.: Influence of sediment gradation on scour downstream of block ramps, Journal of Hydraulic Engineering, Vol. 133, No. 11, pp. 1241-1248, 2007.

8) Pagliara, S., Palermo, M. and Carnacina, I.: Live-bed scour downstream of block ramps for low densimetric Froude numbers, International Journal of Sediment Research, Vol. 27, No. 3, pp. 337-350, 2012.

9) Pagliara, S. and Palermo, M.: Scour control downstream of block ramps, Journal of Hydraulic Engineering, Vol. 134, No. 9, pp. 1376-1382, 2008.

10) Nasrabadi, M., Omid, M. H., and Farhoudi, J.: Submerged hydraulic jump with sediment-laden flow, International Journal of Sediment Research, Vol. 27, pp. 100-111, 2012.

(Received September 30, 2014) 